Berkala Ilmu Perpustakaan dan Informasi, Vol. 15, No. 1, Juni 2019, Hal. 74-86 DOI: 10.22146/bip.40056

ISSN 1693-7740 (Print), ISSN 2477-0361 (Online)

Tersedia online di https://jurnal.ugm.ac.id/bip

\title{
Peran mediasi customer-employee rapport pada pengaruh strategi emotional labor pustakawan terhadap kepuasan pelayanan pengguna perpustakaan
}

\author{
Riska Amaliah ${ }^{1}$, Muhammad Jufri ${ }^{1}$, Resekiani Mas Bakar ${ }^{1}$ \\ ${ }^{1}$ Fakultas Psikologi, Universitas Negeri Makassar \\ Jalan A.P.Pettarani, Makassar, 90222 \\ E-mail: riskaamaliah306@gmail.com
}

Naskah diterima: 25 Oktober 2018, direvisi: 13 Maret 2019, disetujui: 19 April 2019

\begin{abstract}
ABSTRAK
Pendahuluan. Dalam memberikan pelayanan, pustakawan menggunakan strategi emotional labor dalam deep acting atau surface acting. Tujuan studi ini menguji pengaruh strategi emotional labor pustakwan terhadap kepuasan pengguna perpustakaan dimediasi customer-employee rapport.

Metode Penelitian. Studi ekperimen ini adalah between subject design. 86 orang partisipan mahasiswa di Makassar menonton sebuah video interaksi pelayanan perpustakaan yang menggunakan strategi deep acting atau surface acting.

Analisis Data. Uji hipotesis dilakukan dengan analisis Process Hayes untuk menguji model mediasi.

Hasil dan Pembahasan. Strategi emotional labor memengaruhi kepuasan konsumen melalui mediasi customeremployee rapport. Strategi emotional labor secara langsung memengaruhi kepuasan konsumen dan customeremployee rapport. Pustakawan yang menggunakan strategi deep acting meningkatkan kepuasan konsumen dan customer-employee rapport, dibandingkan surface acting. Ekspresi emosi pustakawan dalam bentuk deep acting dapat menularkan emosi positif yang memengaruhi antara pengguna dan pustakawan, sehingga berdampak pada hubungan baik dan kepuasan pelayanan.

Kesimpulan dan Saran. Strategi emotional labor pustakawan berpengaruh terhadap kepuasan pengguna perpustakaan dengan dimediasi oleh customer-employee rapport. Penelitian selanjutnya dapat dilakukan dalam field experiment dan menguji peran gender.
\end{abstract}

Kata kunci: Emotional labor; Customer-Employee Rapport; Kepuasan pengguna perpustakaan.

\section{ABSTRACT}

Introduction. Strategies of Deep Acting and Surface Acting using Emotional Labor in library services have been conducted. The study aims to examine the effect of Emotional Labor on library user satisfaction mediated by Customer-Employee Rapport.

Method. There were 86 participants involved in this experimental study. They were undergraduate students in Makassar who were asked to watch the video related to library services by using Deep Acting or Surface Acting strategies.

Data Analysis. Hypothesis were examined by using Hayes Process analysis to understand the mediation model.

Results and Discussions. Emotional Labor strategy was found to have a relationship to customer satisfaction through Customer-Employee Rapport mediation. Emotional labor strategy was found to have directly affected customer satisfaction and Customer-Employee Rapport. The librarians applied Deep Acting strategy to enhance customer satisfaction and customer-employee rapport was found to be more effective compared to Surface Acting. The librarians' emotional expression in deep acting enables them to transform the positive emotion between librarians and users, thus, it improves good relationships and customer satisfaction.

Conclusion. The librarians' emotional labor strategies effect on library user satisfaction with customeremployee rapport as the mediation variable. Future research should discuss another library experiment based on gender perspectives.

Keywords: Emotional Labor; Customer-Employee Rapport; Library user satisfaction. 


\section{A. PENDAHULUAN}

Perpustakaan perguruan tinggi merupakan jantung dari suatu institusi pendidikan (Mubasyaroh, 2016). Kualitas perpustakaan perguruan tinggi merupakan representasi dari pelayanan yang diberikan. Perpustakaan perguruan tinggi yang berkualitas tidak hanya dapat dinilai dari koleksi dan fasilitas saja, tetapi juga pelayanan dari pustakawan. Pustakawan yang sopan, ramah, bertanggung jawab, empati dan profesional dalam melayani pengguna perpustakaan merupakan aspek penting dalam interaksi di perpustakaan. Namun demikian, terdapat beberapa hal sering dikeluhkan oleh pemustaka. Beberapa keluhan antara lain kesulitan menemukan literatur yang diinginkan, minimnya fasilitas penelusuran informasi, penataan bahan pustaka yang kurang baik, pelayanan yang lambat, kondisi perpustakaan yang berisik, dan sikap pustakawan yang kurang professional (Santoso, 2008). Salah satu keluhan yang menjadi fokus pada penelitian ini adalah kualitas pelayanan pustakawan yang belum memenuhi harapan bagi pengguna. Hasil survei yang dilakukan oleh penulis sebagai data awal studi ini kepada 117 pemustaka perpustakaan di Makassar Indonesia, menunjukkan bahwa terdapat $64.3 \%$ responden yang merasa tidak puas terhadap pelayanan pustakawan, $61.7 \%$ responden merasa bahwa pustakawan bersikap kurang ramah ketika melayani, dan $81.9 \%$ responden mengaku akan mengurangi intensitas kunjungannya ketika mendapatkan pelayanan yang kurang ramah.

Pelayanan yang ramah dapat mempengaruhi kepuasan konsumen dan kedekatan diantara keduanya (Halim \& Suryani, 2013). Kepuasan pengguna perpustakaan sebagian besar dipengaruhi oleh keramahan pustakawan. Keramahan pustakawan merupakan salah satu perilaku yang diharapkan muncul selama berinteraksi dengan pengguna perpustakaan. Aspek penting pustakawan yang sesuai dengan harapan organisasi merupakan bagian dari emotional labor. Hochschild (1983) sebagai tokoh yang memperkenalkan konsep emotional labor mendefinisikan sebagai pengendalian ekspresi emosi dan perasaan karyawan. Emotional labor adalah istilah yang sering digunakan pada karyawan bagian pelayanan dan bersentuhan langsung dengan konsumen, seperti customer service, call operator center, perawat, guru, dokter, dan pustakawan. Emotional labor berdampak pada kesuksesan organisasi, performansi karyawan serta kepuasan konsumen (Ratnaningsih, 2015). Jika konsumen menerima perlakuan yang ramah dan tulus dari karyawan, maka dengan mudah menimbulkan kepuasan konsumen (Grandey, 2015). Secara garis besar, emotional labor terbagi atas dua strategi yaitu deep acting strategy dan surface acting strategy. Karakteristik yang membedakan diantara kedua strategi tersebut yaitu ekspresi wajah, isyarat tubuh, dan juga intonasi suara (Choi \& Kim, 2015). Karakteristik lain adalah conventional greetings (Wu \& Shen, 2013).

Karyawan yang memilih menggunakan strategi deep acting akan berusaha memahami perilaku negatif konsumen, sehingga emosi yang ditampilkan pelayan akan dirasakan tulus. Karyawan yang memilih menggunakan strategi lain yaitu surface acting, akan mengubah emosi dengan mengatur wajah secara terpaksa sehingga terlihat ramah (seperti memakai topeng), dan akan dirasakan tidak tulus oleh konsumen. Penelitian Jung (2015) menunjukkan adanya hubungan signifikan antara strategi deep acting terhadap kepuasan konsumen. Strategi yang terbukti paling memiliki pengaruh positif terhadap kepuasan konsumen adalah deep acting (Lee, Aziz, Sidin, \& Saleh, 2014).

Kepuasan konsumen mengarah pada proses interaksi yang menyenangkan dan nyaman antara konsumen dengan karyawan. Penilaian konsumen mengenai kenyamanan selama proses interaksi disebut dengan customeremployee rapport (Gremler \& Gwinner, 2000; DeWitt \& Brandy, 2003; Hennig-Thurau, Groth, Paul, \& Gremler, 2006). Customer-employee rapport yang tinggi akan menimbulkan perasaan senang dan nyaman dari pemustaka ketika berinteraksi dengan pustakawan, namun hasil survei yang diperoleh menunjukkan bahwa sekitar $67.4 \%$ pemustaka perpustakaan merasa tidak nyaman saat berinteraksi dengan pustakawan. Rasa tidak nyaman tersebut 
dikarenakan pustakawan yang kurang ramah atau terkesan jutek dalam melayani pengguna perpustakaan. Hasil survei tersebut berbanding terbalik dengan kode etik pustakawan yang menuntut para pustakawan untuk melayani dengan santun dan tulus.

Customer-employee rapport secara signifikan terbukti dipengaruhi oleh strategi deep acting. Strategi deep acting terbukti memiliki hubungan yang signifikan dengan customer-employee rapport ( $\mathrm{Wu} \&$ Shen, 2013). Penelitian ini menyimpulkan bahwa dalam proses pelayanan, jika karyawan dapat membuat konsumen merasa bahwa mereka diperlakukan dengan tulus dibandingkan dengan memalsukan emosi, maka akan menimbulkan dampak positif dari konsumen yaitu perasaan senang dan nyaman terhadap proses pelayanan.

Secara khusus, penelitian terkait pengaruh emotional labor terhadap kepuasan konsumen dan customer-employee rapport telah dilakukan dalam eksperimen Henning-Thurau et al. (2006). Hanya saja, penelitian tersebut terbatas pada pengaruh masing-masing variabel secara satu persatu yaitu emotional labor terhadap kepuasan konsumen dan emotional labor terhadap customer-employee rapport. Padahal, kepuasan konsumen dapat dijelaskan dari proses interaksi hubungan yang terbangun dari proses pelayanan. Keterbatasan penelitian tersebut menjadi peluang bagi peneliti dalam menilai variabel customer-employee rapport sebagai mediasi yang mengantarai pengaruh secara tidak langsung antara emotional labor dan kepuasan konsumen.

Berdasarkan beberapa hasil penelitian terdahulu, maka peluang yang dapat diteliti pada studi ini mengacu pada pertanyaan penelitian:

1. Apakah strategi emotional labor pustakawan akan mempengaruhi kepuasan pemustaka yang dimediasi oleh peran customer-employee rapport?

2. Apakah strategi emotional labor pustakawan secara langsung akan mempengaruhi kepuasan pemustaka?

3. Strategi manakah yang memiliki pengaruh lebih besar dalam meningkatkan kepuasan pemustaka?
4. Apakah strategi emotional labor pustakawan secara langsung mempengaruhi customer-employee rapport?

5. Strategi manakah yang memiliki pengaruh lebih besar dalam meningkatkan customeremployee rapport?

Penelitian ini bertujuan untuk menguji pengaruh secara tidak langsung antara strategi emotional labor pustakawan terhadap kepuasan konsumen yang dimediasi oleh peran variabel customer-employee rapport. Penelitian ini juga bertujuan untuk menguji pengaruh langsung antara strategi emotional labor pustakawan terhadap kepuasan konsumen. Pengujian langsung strategi emotional labor pustakawan terhadap customer-employee rapport juga menjadi tujuan penelitian ini.

Penelitian ini memberikan kontribusi dalam menjelaskan pengaruh strategi deep acting dan surface acting terhadap kepuasan konsumen yang belum dijelaskan oleh penelitian sebelumnya, terutama dalam konteks interaksi pelayanan perpustakaan. Peran customer-employee rapport akan memediasi pengaruh tidak langsung antara strategi emotional labor pustakawan terhadap kepuasan pemustaka.

\section{B. TINJAUAN PUSTAKA Kepuasan Konsumen}

Kepuasan merupakan istilah yang tidak asing dalam riset-riset perilaku konsumen. Tingkat kepuasan konsumen dapat dilihat dari penilaian konsumen setelah menggunakan suatu barang atau pelayanan. Kepuasan menjadi faktor yang sangat penting dalam menjaga keberlangsungan suatu bisnis. Setiap organisasi perlu berusaha dalam mencapai kualitas maksimal terhadap produk atau pelayanannya, sehingga mampu memenuhi kebutuhan pelanggan (Nguyen, Nguyen, Nguyen, \& Phan, 2018; Suchánek, Richter, \& Králová, 2015)

Pembahasan tentang kepuasan konsumen merupakan topik yang luas. Kepuasan konsumen dapat berarti penilaian terhadap kualitas barang, mutu produk, tingkat harga, fitur atau fasilitas yang diberikan, lokasi, maupun kualitas proses pelayanan. Pada 
penelitian ini, pembahasan kepuasan konsumen difokuskan pada kepuasan kualitas pelayanan dalam bidang jasa.

Kualitas pelayanan terdiri atas beberapa aspek, yaitu reliabilitas, responsif, jaminan, empati, dan tangible (Gorla, Somers, \& Wong, 2010). Aspek reliabilitas meliputi ketepatan dan konsistensi dalam memberikan pelayanan sesuai dengan janji yang ditawarkan kepada konsumen. Tidak hanya menyangkut konsistensi pelayanan sesuai aturan, tetapi juga berkaitan dengan penerapan harga yang tidak berubah-ubah sesuka hati. Implikasi aspek reliabilitas dalam pelayanan perpustakaan seperti pustakawan memberikan pelayanan sesuai dengan jadwal yang telah ditentukan. Aspek responsif meliputi kecepatan dalam memberikan pelayanan dengan inisiatif dan mandiri. Responsif berarti memberikan perhatian dan ketepatan atas permintaan, kebutuhan, atau keluhan dari konsumen. Implikasi aspek responsif dalam pelayanan perpustakaan seperti kesigapan dan ketanggapan pustakawan dalam layanan pembuatan kartu anggota baru. Aspek ketiga yakni jaminan. Aspek jaminan meliputi kompetensi, kesopanan, dan dapat dipercaya. Implikasi dari aspek jaminan dalam pelayanan perpustakaan seperti kemampuan pustakawan yang kompeten dalam memberikan informasi kepada pemustaka, sehingga merasa terjamin dan yakin. Aspek empati meliputi perhatian yang bersifat personal kepada konsumen, termasuk kemampuan komunikasi dan memahami kebutuhan pemustaka. Implikasi dari aspek empati dalam pelayanan perpustakaan seperti sikap pustakawan dalam memberikan perhatian kepada pemustaka. Aspek terakhir adalah tangibles. Aspek tangibles meliputi penampilan fisik yang melekat pada penyedia jasa, termasuk fasilitas, teknologi, sarana dan prasarana pendukung proses layanan. Implikasi aspek tangibles dalam pelayanan perpustakaan seperti penampilan pustakawan yang bersih, rapi, dan sopan.

Ada beberapa faktor yang mempengaruhi kepuasan konsumen, salah satunya proses pelayanan atau dikenal dengan service encounter. Service encounter dalam praktiknya tidak sekedar melibatkan transaksi ekonomi antara penyedia layanan dan konsumen, tetapi juga proses interaksi yang melibatkan aspek emosi diantara keduanya. Karakteristik service encounter dapat dilihat dalam empat ciri proses layanan yaitu profesionalisme penyedia jasa, kompetensi, sopan santun dan ekspresi emosi. Pengaturan ekspresi emosi karyawan pada bidang layanan adalah aspek yang penting untuk diperhatikan bagi pimpinan atau perusahaan (Devi, 2016). Ekspresi emosi seperti menampilkan wajah ramah dan tersenyum menjadi tuntutan pada karyawan bagian pelayanan. Sebaliknya ekspresi negatif seperti marah atau sombong tidak diperbolehkan untuk diperlihatkan. Hal tersebut akan berdampak pada situasi pelayanan yang tidak menyenangkan.

\section{Customer-Employee Rapport}

Dalam memberikan pelayanan, elemen yang nyata maupun yang tidak nyata dapat menjadi penilaian pelanggan (Kim \& Baker, 2017). Salah satu elemen yang tidak nyata yakni customer-employee rapport. Customeremployee rapport mengacu pada penilaian pelanggan terhadap interaksi pelayanan yang diperoleh. Customer-employee rapport ini terdiri dari dua aspek, yaitu interaksi yang menyenangkan dan koneksi pribadi. Penilaian tentang kualitas rapport tergantung pada satu atau beberapa interaksi yang terjadi antara konsumen dan penyedia layanan (HennigThurau et al., 2006). Dell (Wu \& Shen, 2013) menuliskan bahwa rapport yang berkualitas akan menimbulkan interaksi yang harmonis dan interaktif antara satu pihak dengan pihak lain.

Customer-employee rapport merepresentasikan aspek emosional dan afektif dari interaksi pelanggan dan karyawan (Biedenbach, Bengtsson, \& Wincent, 2011). Emosi yang ditampilkan oleh karyawan selama memberikan pelayanan dapat menular kepada pelanggan dan membangun persepsi positif pelanggan terhadap brand yang bersangkutan. Membangun ketertarikan yang tulus kepada konsumen merupakan awal dari hubungan personal. Hubungan yang terbangun meliputi pertukaran informasi yang bersifat personal dan 
berkaitan dengan penyediaan layanan. Hubungan personal merupakan ciri yang mendukung pencapaian kepuasan konsumen serta loyalitas.

\section{Strategi Emotional Labor}

Hochschild, seorang sosiolog yang pertama kali menggunakan istilah emotional labor sebagai "the management of feeling to create a publicly observable facial and bodily display" (Hochschild, 1983). Terdapat tiga karakteristik pekerjaan yang termasuk dalam manajemen emosi adalah: (1) adanya tatap muka (face to face) atau suara (voice to voice) antara karyawan dengan konsumen, (2) adanya tuntutan kerja bagi karyawan yang melibatkan emosi, dan (3) adanya kontrol dari perusahaan yang mengatur aktivitas emosi karyawan. Individu yang merupakan social worker sangat berkaitan dengan proses pelayanan, baik itu di bidang pendidikan, dan kesehatan, sosial atau psikolog (Roh, Moon, Yang, \& Jung, 2016). Kondisi tersebut menuntut penggunaan emotional labor dalam proses interaksi dengan pelanggan. Tuntutan organisasi yang diberikan bagi para karyawan dalam menampilkan emosi selama proses pelayanan disebut dengan emotional labor (Groth, Hennig-Thurau, \& Walsh, 2009).

Konsep emotional labor merupakan metode dari regulasi emosi yang berlangsung sementara dan dinamis pada individu (Grandey \& Melloy, 2017). Emotional labor terdiri dari dua strategi, yaitu deep acting dan surface acting. Deep acting dan surface acting mengacu pada cara karyawan mengelola emosi internal dan menampilkan emosi dalam bentuk ekspresi serta sikap (Tang, Seal, Naumann \& Miguel, 2013). Strategi pertama yaitu deep acting. Strategi ini meliputi pengelolaan emosi internal dan tuntutan perusahaan, sehingga benar-benar merasakan emosi positif ketika memberikan pelayanan. Memodifikasi emosi yang dirasakan sehingga sesuai dengan tampilan yang diinginkan oleh perusahaan adalah ciri dari deep acting (Groth, Hennig-Thurau \& Walsh, 2009). Strategi kedua yaitu surface acting. Berbeda dengan deep acting, surface acting adalah pemalsuan emosi dalam memenuhi tuntutan kerja (Grandey, 2003). Surface acting meliputi pemalsuan emosi yang ditampilkan, hanya seolah-olah tampak positif padahal tidak sesuai dengan kondisi internal karyawan. Pemalsuan emosi dapat menyebabkan terjadinya disonansi emosi karena tidak sinkron antara emosi internal dan ekspresi maupun sikap yang ditampilkan ketika memberikan pelayanan.

\section{Strategi Emotional labor, Kepuasan Konsumen, dan Customer-Employee rapport}

Beberapa penelitian menunjukkan dengan jelas bahwa deep acting berhubungan positif dengan kepuasan konsumen. Karyawan yang menggunakan strategi deep acting saat melayani konsumen akan membuat perilaku tersebut sebagai kebiasaan kerja mereka, sehingga secara positif mempengaruhi budaya organisasi. Hal tersebut dikarenakan karyawan yang awalnya melakukan strategi deep acting sebagai kebiasaan kerja untuk memuaskan konsumen, kemudian diterjemahkan oleh konsumen sebagai budaya organisasi.

Surface acting hanya melibatkan pemalsuan emosi karyawan, sehingga cenderung untuk tidak menunjukkan perhatian dan ekspresi positif yang dapat dengan mudah diidentifikasi oleh konsumen dan menyebabkan ketidakpuasan konsumen (Wessel \& Steiner, 2015). Karyawan yang menggunakan strategi surface acting ketika melayani cenderung tidak menunjukkan komitmen kepada konsumen namun hanya berusaha menyembunyikan emosi negatif yang sedang dirasakan. Komitmen terhadap konsumen sangat diperlukan agar kepuasan dapat terjadi.

Penelitian Lee et al. (2014) membuktikan pengaruh strategi deep acting dan surface yang digunakan pemandu wisata terhadap kepuasan konsumen. Hal tersebut dikarenakan konsumen cenderung lebih menghargai karyawan ketika menampilkan emosi yang lebih alami sehingga konsumen merasa diperlakukan dengan tulus yang mengakibatkan peningkatan kepuasan terhadap pelayanan. Surface Acting memiliki pengaruh negatif terhadap kepuasan konsumen, hal ini disebabkan konsumen akan merasa bahwa karyawan tidak tulus dan tidak bersedia melakukan pelayanan. Dampaknya konsumen secara langsung atau tidak langsung dapat 
membatasi interaksi dengan karyawan tersebut.

Penelitian yang dilakukan oleh Jung (2015) pada perusahaan home care di Korea Selatan menunjukkan bahwa strategi emotional labor mempengaruhi kepuasan konsumen yang dimediasi oleh kepuasan kerja karyawan. Konsumen mengetahui bahwa karyawan memperlakukan konsumen karena mereka digaji untuk itu, sehingga persepsi konsumen mengenai surface acting tidak secara langsung mempengaruhi evaluasi negatif layanan. Deep acting yang tinggi memungkinkan perusahaan membangun hubungan kuat antara karyawan dan konsumen, sehingga menghasilkan kepuasan konsumen.

Hasil meta-analysis yang dilakukan oleh Lo \& Huang (2017) menunjukkan bahwa perusahaan atau organisasi yang mementingkan tingkat kepuasan konsumen yang tinggi harus berfokus dalam menanamkan strategi deep acting pada karyawan dibandingkan surface acting. Hal tersebut dikarenakan surface acting tidak dapat secara alami menunjukkan komitmen dan dedikasinya dalam melayani sehingga tidak menyebabkan kepuasan konsumen.

Penelitian Henning-Thurau et al. (2006) membuktikan bahwa pelayanan deep acting mempengaruhi penilaian customer-employee rapport yang lebih tinggi dibandingkan pelayanan surface acting. Strategi deep acting yang ditampilkan karyawan dipersepsikan sebagai keakraban dan keramahan oleh konsumen, sehingga interaksi antar kedua belah pihak menghasilkan rapport yang tinggi. Strategi surface acting yang ditampilkan oleh karyawan dipersepsikan sebagai keramahan yang tidak alami oleh konsumen sehingga tidak menghasilkan rapport yang tinggi. Karyawan yang dapat membuat konsumen diperlakukan dengan tulus (deep acting) dibandingkan dengan memalsukan emosi (surface acting), maka akan menimbulkan dampak positif dari konsumen yaitu perasaan senang dan nyaman terhadap proses pelayanan (Wu \& Shen, 2013).

Customer-employee rapport merupakan salah satu aspek penting dalam sebuah organisasi yang memberikan jasa pelayanan (Lin \& Lin, 2017). Penelitian sebelumnya menunjukkan bahwa rapport antara pelanggan dan karyawan dapat memediasi peningkatan kepuasan konsumen dan afektif komitmen terhadap suatu brand (W. Kim \& Ok, 2010). Jika customer-employee rapport telah terbukti memiliki pengaruh terhadap kepuasan konsumen, maka memungkinkan mekanisme ini digunakan sebagai mediasi antara strategi emotional labor dan kepuasan konsumen.

$\mathrm{H}_{1}$ : Terdapat pengaruh emotional labor pustakawan terhadap kepuasan pemustaka, dimediasi oleh customeremployee rapport.

$\mathrm{H}_{2}$ : Terdapat pengaruh strategi emotional labor terhadap kepuasan pemustaka. Strategi deep acting memiliki pengaruh yang lebih tinggi terhadap kepuasan pemustaka, dibandingkan strategi surface acting.

$\mathrm{H}_{2}$ : Terdapat pengaruh strategi emotional labor terhadap customer-employee rapport. Strategi deep acting memiliki pengaruh yang lebih tinggi terhadap customeremployee rapport, dibandingkan strategi surface acting.

\section{METODE PENELITIAN}

Tujuan eksperimen ini untuk menguji pengaruh strategi emotional labor terhadap kepuasan pemustaka, dimediasi oleh customeremployee rapport. Stimulus eksperimen diberikan dalam bentuk video. Partisipan ditempatkan pada salah satu dari kelompok strategi emotional labor yaitu deep acting atau surface acting.

Desain. Desain eksperimen adalah one independent variable between participant dengan dua kondisi (deep acting atau surface acting).

Partisipan. 86 orang partisipan perempuan berusia antara 18-23 tahun. Partisipan ditempatkan pada kelompok deep acting $(\mathrm{N}=$ 49) dan kelompok surface acting $(\mathrm{N}=37)$. Partisipan yang ikut serta pada penelitian ini merupakan mahasiswa pada universitas negeri maupun swasta di kota Makassar, Sulawesi Selatan, Indonesia.

Pilot Study. Dalam upaya untuk menentukan video stimulus eksperimen dilakukan pilot studi. Pilot studi bertujuan untuk mendapatkan 
data mengenai apakah manipulasi video yang akan digunakan pada penelitian sesuai dengan karakteristik pustakawan yang akan diukur. Adapun karakteristik pustakawan yang akan diukur yaitu senyuman, kontak mata, keramahan, sikap responsif, dan emosi dalam skala 1 (sangat tidak sesuai) - 4 (sangat sesuai). Pilot study dilakukan kepada 30 mahasiswi, $\left(\mathrm{N}_{\text {video-deepacting }}=15 ; \mathrm{N}_{\text {video-surfacepacting }}=15\right)$. Hasil pilot studi video stimulus eksperimen dapat dilihat pada Tabel 1.

\section{Material dan Aparatus Penelitian}

Video. Manipulasi eksperimen ini terdiri atas video deep acting dan surface acting yang dibuat sendiri oleh penulis dengan menggunakan aktor. Aktor dalam video terdiri dari dua orang yang memerankan peran sebagai seorang pustakawan dan seorang pemustaka. Video berisikan interaksi antara pustakawan dan pemustaka dalam konteks perpustakaan. Instruksi video adalah "Anda akan diperlihatkan sebuah video. Tugas Anda adalah menonton video tersebut dengan seksama". Total durasi video deep acting adalah 267 detik (4 menit-27 detik) dan surface acting adalah 235 detik (3 menit-55 detik).

Laptop. Video pada penelitian ini ditampilkan melalui layar laptop MacBook Air seri Mid 2012; ukuran 11 inchi; sistem OS version 10.13.2; dan kapasitas hardisk 4 GB. Audio dari video diperdengarkan kepada partisipan melalui headphone ALFA LINK tipe BTH 130; diameter speaker $40 \mathrm{~mm}$; frekuensi $20 \mathrm{~Hz}-20$ $\mathrm{KHz}$.

Skala Kepuasan Pelayanan. Kepuasan pengguna perpustakaan diukur dengan skala yang diadaptasi dari skala yang digunakan Bakar \& Himam (2009) sejumlah 16 item. Skala kepuasan pelayanan pustakawan meliputi lima aspek, yaitu reliabilitas, responsif, jaminan, empati dan tangibles. Skala kepuasan pelayanan pustakawan memiliki reliabilitas sebesar 0.95. Contoh item: "Pustakawan secara konsisten bersikap ramah dalam memberikan pelayanan kepada pemustaka". Penilaian kepuasan konsumen diukur dengan memilih respon sangat tidak sesuai (1) - sangat sesuai (4).
Skala customer-employee rapport. Penilaian partisipan terhadap customer-employee rapport menggunakan skala adaptasi dari Gremler \& Gwinner (2000) sebanyak 10 item. Skala yang digunakan telah dimodifikasi kembali oleh peneliti berdasarkan tujuan penelitian. Customer-employee rapport meliputi dua aspek yaitu interaksi yang menyenangkan (enjoyable interaction) dan hubungan personal (personal connection). Reliabilitas skala sebesar 0.96. Contoh item: "pemustaka nyaman berinteraksi dengan pustakawan". Penilaian kepuasan konsumen diukur dengan memilih respon sangat tidak sesuai (1) - sangat sesuai (4).

Manipulation check. Pemberian lembar manipulation check dilakukan setelah partisipan mengisi lembar skala customer-employee rapport. Item pertanyaan "Pustakawan yang ada di video melayani pemustaka dengan". Penilaian cek manipulasi diukur dengan memilih jawaban tulus atau tidak tulus.

Prosedur. Eksperimen dilakukan secara individual. Partisipan datang dan menuju ke ruang eksperimen. Eksperimenter menyambut dan mempersilahkan partisipan memasuki ruang eksperimen. Eksperimenter memberikan instruksi kepada partisipan. Eksperimenter memberikan kesempatan kepada partisipan untuk membaca dan menandatangani informed consent, sebelum eksperimen dimulai. Eksperimenter meminta partisipan untuk menonton video dengan seksama. Eksperimenter mulai memutar video berdasarkan kelompok partisipan yaitu deep acting atau surface acting. Video ditampilkan pada monitor laptop dengan menggunakan headphone. Setelah partisipan selesai menonton, maka diminta untuk mengisi skala kepuasan pelayanan konsumen, skala customeremployee rapport, dan lembar manipulation check. Di akhir, eksperimenter melakukan debrief dan penutup.

\section{HASIL DAN PEMBAHASAN}

Manipulation Check. Hasil manipulation check menunjukkan terdapat 14 orang partisipan yang tidak dapat digunakan karena memilih respon yang tidak sesuai dengan kondisi eksperimen. 


\section{Pengaruh Strategi Emotional Labor terhadap Kepuasan pemustaka, dimediasi oleh Customer Employee Rapport}

Analisis data membuktikan bahwa pelayanan deep acting lebih tinggi menilai kepuasan pemustaka, daripada kelompok pelayanan surface acting $\left(\mathrm{M}_{\text {dep-acting }}=3.5, \mathrm{SE}=\right.$ $\left.0.04 ; \mathrm{M}_{\text {surface acting }}=2.4, \mathrm{SD}=0.06\right)$. Uji-t menunjukkan bahwa perbedaan yang signifikan strategi emotional labor pada kelompok surface acting dan deep acting terhadap kepuasan pemustaka, $t(84)=13.885, p<0,05,95 \% \mathrm{CI}$ [0.908 - 1.212]. Partisipan pada kelompok deep acting lebih tinggi penilaian customer-employee rapport $\left(\mathrm{M}_{\text {deep-acting }}=3.16, \mathrm{SE}=0.04\right)$, dibandingkan pada kelompok surface acting $\left(\mathrm{M}_{\text {surface-acting }}=2.24, \mathrm{SD}=0.77\right) . \mathrm{Uji}-\mathrm{t}$ menunjukkan bahwa perbedaan yang signifikan strategi emotional labor pada kelompok surface acting dan deep acting terhadap customeremployee rapport, $t(84)=10.673, p<0,05,95 \%$ CI [0.08-0.74].

Uji simple linear regression dilakukan untuk melihat pengaruh hubungan antara strategi emotional labor terhadap kepuasan pemustaka. Dari uji regresi diketahui bahwa terdapat pengaruh signifikan antara strategi emotional labor terhadap kepuasan konsumen, $F(1,84)=181.359, p<0,05$. Nilai $\mathrm{R}^{2}$ sebesar 0.683 menunjukkan bahwa sekitar $68.3 \%$ kepuasan pemustaka diprediksi oleh strategi emotional labor. Strategi emotional labor secara signifikan berpengaruh positif terhadap pemustaka, $b=4.59$, t (84) $=42.29, p<0,05$.

Analisis regresi dengan prosedur process membuktikan hipotesis bahwa strategi emotional labor berpengaruh positif terhadap kepuasan pemustaka, melalui mediasi customer-employee rapport. Hasil ini menunjukkan bahwa secara tidak langsung, variabel customer-employee rapport berperan dalam pengaruh antara strategi emotional labor terhadap kepuasan konsumen. Peran customeremployee rapport dalam penelitian ini membuktikan bahwa ketika pustakawan menggunakan salah satu strategi emotional labor dalam berinteraksi dengan pemustaka, maka memengaruhi juga kuat tidaknya efek terhadap kepuasan konsumen. Menggunakan strategi emotional labor dapat menimbulkan dampak secara emosi atas interaksi hubungan yang terjadi antara pustakawan dan pemustaka. Lebih lanjut bahwa dengan terjadinya efek secara emosi dari interaksi tersebut, maka mempengaruhi kepuasan konsumen. Bila interaksi yang terjadi menimbulkan hubungan emosi yang positif, maka meningkatkan kepuasan konsumen. Sebaliknya, bila interaksi yang terjadi menimbulkan emosi negatif, maka menurunkan kepuasan konsumen.

Hasil penelitian ini menunjukkan hubungan signifikan antara strategi emotional labor dengan kepuasan melalui customer-employee rapport. Mekanisme ini dapat dijelaskan melalui konsep emotional contagion. Emotional contagion adalah perpindahan emosi yang dapat terjadi dalam kehidupan sosial (Hennig-Thurau et al., 2006). Penularan emosi terjadi melalui proses imitasi yang berlangsung secara tidak disadari atas gerak tubuh, ekspresi wajah, intonasi suara, maupun gaya bicara seseorang. Penularan emosi ini dapat mengakibatkan kedekatan emosional karena terjadi internalisasi emosi seseorang kepada orang yang lain. Hasil penelitian ini dapat dilihat pada Tabel 2 .

Pustakawan pada strategi deep acting memberikan pelayanan dengan menampilkan senyum tulus, intensitas menatap pemustaka disertai bahasa tubuh positif. Bahasa tubuh yang positif ditampilkan melalui sikap berdiri ketika pengguna pertama kali datang, menyapa dengan hangat, mempersilahkan untuk duduk terlebih dahulu, dan intonasi suara lembut. Senyum tulus dan sikap tubuh yang positif berdampak pada terciptanya hubungan customer-employee rapport yang memadai.

Pada sisi lain, pustakawan pada strategi surface acting memberikan pelayanan dengan menampilkan senyum datar atau kurang tulus, kurang intensitas menatap pemustaka, menunjukkan sikap tubuh yang kurang terbuka, tidak mempersilahkan duduk dan berintonasi kurang semangat saat proses pelayanan berlangsung. Sikap tubuh dan ekspresi yang ditampilkan seolah-olah nampak hanya sekedar menjalankan prosedur pelayanan secara mekanik. Hal tersebut berdampak pada penularan emosi yang kurang positif. Secara 
tidak disadari, pemustaka mengimitasi sikap dan ekspresi tersebut, sehingga berdampak pada terbangunnya customer-employee rapport yang rendah. Dampak dari hubungan yang terbangun antara pemustaka dan pustakawan berpengaruh terhadap kepuasan. Ketika customer-employee rapport tinggi, maka kepuasan konsumen juga akan meningkat. Sebaliknya ketika customeremployee rapport rendah, maka kepuasan konsumen akan menurun.

\section{Pengaruh Strategi Emotional Labor Pustakawan terhadap Kepuasan pemustaka}

Penelitian terdahulu telah secara terpisah menunjukkan pengaruh positif antara deep acting terhadap kepuasan konsumen, dan pengaruh customer-employee rapport terhadap kepuasan konsumen. Studi eksperimen melakukan pengujian pengaruh secara langsung strategi emotional labor (deep acting vs. surface acting) pustakawan terhadap kepuasan pemustaka, maupun pengaruh tidak langsung melalui customer-employee rapport (Gambar 1). Hasil studi menunjukkan bahwa pelayanan pustakawan deep acting atau surface acting menimbulkan perbedaan mean kepuasan yang dinilai oleh pemustaka. Hal ini dapat dilihat dari perbedaan respon jawaban partisipan kedua kelompok. Partisipan kelompok deep acting $100 \%$ setuju bahwa pustakawan cepat dan tanggap dalam melayani pemustaka, sebaliknya pada partisipan surface acting hanya 54\%. Demikian pula pada respon penilaian terhadap kenyamanan dalam berkomunikasi dengan pustakawan, semua partisipan deep acting setuju menilai dan 52\% partisipan surface acting yang tidak setuju. Dalam hal keramahan pustakawan, semua partisipan kelompok deep acting (100\%) menilai setuju dan hanya 51\% partisipan surface acting. Pustakawan menunjukkan intensitas tersenyum pada kelompok deep acting (100\%) dan kelompok surface acting $(8,1 \%)$.

Hasil ini sesuai dengan pendapat (Wessel \& Steiner, 2015) yang berpendapat bahwa surface acting hanya melibatkan pemalsuan emosi karyawan, sehingga cenderung untuk tidak menunjukkan perhatian dan ekspresi positif yang dapat dengan mudah diidentifikasi oleh konsumen sehingga menyebabkan ketidakpuasan konsumen. Konsumen cenderung lebih menghargai karyawan ketika menampilkan emosi yang lebih alami sehingga konsumen merasa diperlakukan dengan tulus yang mengakibatkan peningkatan kepuasan terhadap pelayanan (Lee et al., 2014). Sedangkan strategi surface acting memiliki pengaruh negatif terhadap kepuasan konsumen, hal ini disebabkan konsumen akan merasa bahwa karyawan tidak tulus dan tidak bersedia melakukan pelayanan. Dampaknya konsumen secara langsung atau tidak langsung dapat membatasi interaksi dengan karyawan tersebut.

Strategi deep acting dapat menyebabkan kepuasan pelayanan dikarenakan karakteristik ekspresi positif seperti menampilkan senyuman yang authentic, sering melakukan kontak mata dan berintonasi ramah dengan konsumen ketika sedang melakukan pelayanan. Di sisi lain, ekspresi wajah seperti kurang ramah dan sedih atau marah tidak diperkenankan untuk ditampilkan selama interaksi, karena dapat menyebabkan penilaian tidak menyenangkan. Partisipan pada surface acting memberikan kesan bahwa proses pelayanan yang diperagakan oleh pustakawan dalam video nampak kurang ramah bahkan cenderung marah kepada pemustaka.

\section{Pengaruh Strategi Emotional Labor Pustakawan terhadap Customer-Employee Rapport}

Studi eksperimen ini menunjukkan perbedaan penilaian customer-employee rapport pada kedua strategi emotional labor (deep acting dan surface acting). Semua individu pada kelompok deep acting menilai bahwa pustakawan mampu membangun hubungan yang hangat dengan pemustaka, sedangkan pada kelompok surface acting hanya sekitar 32\% yang menilai hal tersebut. Sebanyak 97\% partisipan kelompok deep acting menilai bahwa terjalin hubungan harmonis antara pustakawan dan pemustaka, dan hanya 32\% kelompok surface acting yang menilai demikian. $84 \%$ partisipan kelompok surface acting menilai tidak ada ikatan dengan pustakawan, sebaliknya $77.5 \%$ kelompok deep 
acting menilai terdapat ikatan di antara kedua pihak. Respon ini sejalan dengan penilaian kelompok surface acting (8\%) dan kelompok deep acting (61\%) yang menilai bahwa pengguna perpustakaan memiliki hubungan yang dekat dengan pustakawan.

Hasil tersebut sesuai dengan pendapat yang dikemukakan oleh Henning-Thurau et al. (2006) bahwa strategi deep acting yang ditampilkan karyawan dipersepsikan sebagai keakraban dan keramahan oleh konsumen, sehingga interaksi antar kedua belah pihak menghasilkan rapport yang tinggi. Strategi deep acting dapat menyebabkan customer-employee rapport yang tinggi dikarenakan karakteristik dalam strategi deep acting berhubungan dengan faktor yang mempengaruhi customer-employee rapport. Salah satu faktor yang mempengaruhi customer-employee rapport adalah courteous behavior atau perilaku sopan. Sikap sopan santun dapat membantu karyawan dalam membentuk bonding dengan konsumen dan menciptakan hubungan yang diperlukan untuk layanan yang positif (Gremler \& Gwinner, 2000). Perilaku sopan sering kali mencakup tindakan sederhana yang membuat sebuah interaksi menjadi menyenangkan.

Salah satu karakteristik deep acting ialah karyawan harus bisa melakukan bonding kepada konsumen seperti berterima kasih ataupun menanyakan hal-hal diluar pelayanan (Wu \& Shen, 2013). Selain itu, deep acting bisa secara langsung mempengaruhi customeremployee rapport karena emosi alami yang ditampilkan karyawan dianggap sebagai keramahan dan kesopanan ketika melayani (Grandey, Fisk, Mattila, Jansen, \& Sideman, 2005).

\section{E. KESIMPULAN}

Studi eksperimen ini membuktikan secara signifikan bahwa customer-employee rapport menjadi variabel yang memediasi pengaruh antara strategi emotional labor pustakawan terhadap kepuasan pemustaka. Penelitian ini membuktikan bahwa kepuasan konsumen menjadi dampak yang dihasilkan dari strategi emotional labor yang digunakan oleh pustakawan. Pustakawan yang menggunakan strategi deep acting dinilai memberikan pelayanan perpustakaan lebih puas dan lebih tinggi customer-employee rapport, dibandingkan pada pustakawan surface acting.

Implikasi penelitian ini bagi perpustakaan yakni menciptakan atmosfir budaya melayani dengan tulus (authenticity). Budaya melayani secara tulus dan didukung oleh keterampilan dan pengetahuan tentang pelayanan yang memadai dari setiap pustakawan berdampak pada kepuasan pemustaka dan reputasi perpustakaan. Keterampilan dalam menggunakan strategi deep acting dapat diperoleh melalui program pelatihan dan pengembangan. Komitmen dari pimpinan perpustakaan dalam menjalankan pelayanan tulus dari hati menjadi fondasi yang kuat dalam mendukung implikasi strategi deep acting pustakawan. Menciptakan budaya melayani, pelatihan strategi deep acting, dan komitmen dari pimpinan perlu untuk senantiasa dilakukan agar dapat meningkatkan intensitas kunjungan dan menunjang eksistensi perpustakaan.

Keterbatasan penelitian ini hendaknya menjadi perhatian bagi peneliti selanjutnya. Pertama, eksperimen ini memanipulasi strategi emotional labor melalui video dalam setting laboratorium. Penelitian selanjutnya dapat dilakukan dengan metode field eksperimen menggunakan aktor pustakawan yang lebih natural. Kedua, partisipan pada studi eksperimen ini yakni perempuan karena pertimbangan aktor pustakawan yang digunakan dalam video juga berjenis kelamin perempuan. Pada studi selanjutnya dapat dikembangkan dengan menguji aktor pustakawan yang berbeda jenis kelamin dengan partisipan yang akan menilai.

\section{DAFTAR PUSTAKA}

Biedenbach, G., Bengtsson, M., \& Wincent, J. (2011). Brand equity in the professional service context: Analyzing the impact of employee role behavior and customeremployee rapport. Industrial Marketing Management, 40(7), 1093-1102. https://doi.org/10.1016/j.indmarman.2011. 09.007 
Choi, Y.-G., \& Kim, K.-S. (2015). A literature review of emotional labor and emotional labor strategies. Universal Journal of Management, 3(7), 294-301. https:// doi.org/10.13189/ujm.2015.030704

Gorla, N., Somers, T. M., \& Wong, B. (2010). Organizational impact of system quality, information quality, and service quality. Journal of Strategic Information Systems, 19(3), 207-228. https://doi.org/10.1016/ j.jsis. 2010.05 .001

Grandey,A.A. (2015). Smiling for a wage: What emotional labor teaches us about emotion regulation. Psychological Inquiry, 26(1), 54-60. https://doi.org/10.1080/1047840X. 2015.962444

Grandey, A. A., Fisk, G. M., Mattila, A. S., Jansen, K. J., \& Sideman, L. A. (2005). Is "service with a smile" enough? Authenticity of positive displays during service encounters. Organizational Behavior and Human Decision Processes, 96(1), 38-55. https://doi.org/10.1016/ j.obhdp.2004.08.002

Grandey, A. A., \& Melloy, R. C. (2017). The state of the heart: Emotional labor as emotion regulation reviewed and revised. Journal of Occupational Health Psychology, 22(3), 407-422. https://doi.org/10.1037/ocp0000067

Gremler, D. D., \& Gwinner, K. P. (2000). Customer-employee rapport in service relationships. Journal of Service Research, 3(1), 82-104. https://doi.org/10.1177/ 109467050031006

Groth, M., Hennig-Thurau, T., \& Walsh, G. (2009). Customer reactions to emotional labor: The roles of employee acting strategies and customer detection accuracy. Academy of Management Journal, 52(5), 958-974. https://doi.org/10.5465/ amj.2009.44634116

Halim, C., \& Suryani, T. (2013). Pengaruh keramahan, kredibilitas dan citra karyawan terhadap kedekatan karyawan dan kepuasan nasabah produk tabungan bank konvensional di Surabaya. Journal of Business and Banking, 3(1), 81 . https://doi.org/ 10.14414/jbb.v3i1.256
Hennig-Thurau, T., Groth, M., Paul, M., \& Gremler, D. D. (2006). Are all smiles created equal? How emotional contagion and emotional labor affect service relationships. Journal of Marketing, 70, 58-73. https://doi.org/10.1509/ jmkg. 70.3 .58

Hochschild, A. R. (1983). The managed heart: Commercialization of human feeling. California: University of California Press

Kim, K., \& Baker, M. A. (2017). How the employee looks and looks at you: Building customer-employee rapport. Journal of Hospitality and Tourism Research, 20(10), 1-21. https://doi.org/10.1177/ 1096348017731130

Kim, W., \& Ok, C. (2010). Customer orientation of service employees and rapport: Influences on service-outcome variables in full-service restaurants. Journal of Hospitality and Tourism Research, 34(1), 34-55. https://doi.org/10.1177/ 1096348009344234

Lee, S. Y., Aziz, Y. A., Sidin, S. M. D., \& Saleh, R. (2014). The influence of emotional labour strategies on customer satisfaction and word of mouth recommendations in group tours. International Journal of Economics and Management, 8 (Special issue), 81-96.

Mubasyaroh, M. (2016). Pengaruh perpustakaan bagi peningkatan mutu pendidikan perguruan tinggi. LIBRARIA: Jurnal Perpustakaan, 4(1), 77. https:// doi.org/10.21043/libraria.v4i1.1246

Nguyen, H. T., Nguyen, H., Nguyen, N. D., \& Phan, A. C. (2018). Determinants of customer satisfaction and loyalty in vietnamese life-insurance setting. Sustainability, 10, 1-16. https://doi.org/ $10.3390 / \mathrm{su} 10041151$

Ratnaningsih. (2015). Manajemen emosi sesuai tuntutan kerja (emotional labor) ditinjau dari tipe kepribadian pada wiraniaga. Jurnal Psikologi Undip, 14(1), 21-28. https://doi.org/10.14710/jpu.14.1.21-28 
Roh, C. Y., Moon, M. J., Yang, S. B., \& Jung, K. (2016). Linking emotional labor, public service motivation, and job satisfaction: Social workers in health care settings. Social Work in Public Health, 31(2), 43-57. https://doi.org/10.1080/19371918.2015.10 87904.

Santoso, H. (2008). Strategi perpustakaan perguruan tinggi dalam menghadapi ketidakpuasan (keluhan ) pemakai. Diakses dari http://digilib.um.ac.id/images/ stories/pustakawan/pdfhasan/

Suchánek, P., Richter, J., \& Králová, M. (2015). Customer satisfaction, product quality and performance of company. Review of Economic Perspective, 14(4), 329-344. https://doi.org/10.1515/revecp-2015-0003
Wessel, J. L., \& Steiner, D. D. (2015). Surface acting in service: A two-context examination of customer power and politeness. Human Relations, 68(5), 709-730. https://doi.org/10.1177/ 0018726714540731

Wu, C. H. J., \& Shen, C. H. (2013). Factors affecting customer positive emotion and service relation-restaurants in hotel as examples. International Journal of Business Tourism and Applied Sciences, $1(2), 30-41$ 


\section{DAFTAR GAMBAR}

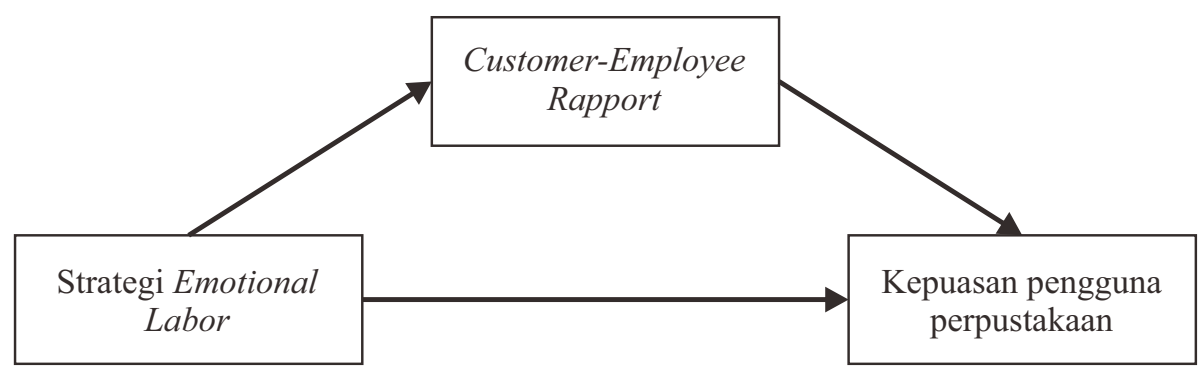

Gambar 1. Model Pengaruh Strategi Emotional Labor Pustakawan terhadap Kepuasan Pengguna Perpustakaan melalui Mediasi Customer-Employee Rapport

\section{DAFTAR TABEL}

Tabel 1. Hasil pilot studi video stimulus eksperimen

\begin{tabular}{llcc}
\hline Video & Penilaian & Mean & SD \\
\hline Deep acting & Senyuman & 3.20 & 0.86 \\
& Kontak mata & 3.6 & 0.83 \\
& Keramahan & 3.39 & 0.26 \\
& Responsif & 3.80 & 0.41 \\
& Aspek emosi & 3.73 & 0.45 \\
\hline Surface acting & Senyuman & 1.73 & 0.45 \\
& Kontak mata & 1.93 & 0.45 \\
& Keramahan & 2.00 & 0.65 \\
& Responsif & 2.47 & 0.74 \\
& Aspek emosi & 2.07 & 0.70 \\
\hline
\end{tabular}

Tabel 2. Estimasi pengaruh strategi emotional labor (SEL) terhadap kepuasan pengguna perpustakaan (CS) dengan mediasi customer-employee rapport (CER)

\begin{tabular}{|c|c|c|c|c|c|c|c|c|}
\hline \multirow[b]{3}{*}{ Antecedent } & \multicolumn{8}{|c|}{ Consequence } \\
\hline & \multicolumn{4}{|c|}{$\mathrm{M}$ (CER) } & \multicolumn{4}{|c|}{$\mathrm{Y}(\mathrm{CS})$} \\
\hline & & Coeff. & SE & $p$ & & Coeff. & SE & $p$ \\
\hline X (SEL) & $a$ & -0.92 & 0.86 & 0.00 & 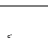 & -0.51 & 0.08 & 0.00 \\
\hline M (CER) & & & & & $b$ & 0.60 & 0.07 & 0.00 \\
\hline \multirow[t]{2}{*}{ Constant } & $i_{1}$ & 4.08 & 0.13 & 0.00 & $i_{2}$ & 2.16 & 0.31 & 0.00 \\
\hline & \multicolumn{3}{|c|}{$\mathrm{R}^{2}=0.575$} & 001 & & \multicolumn{3}{|c|}{$\mathrm{R}^{2}=0.835$} \\
\hline
\end{tabular}

